\title{
Severe Eosinophilic Allergic Asthma Responsive to Mepolizumab After Failure of 2 Consecutive Biologics
}

Sánchez-Jareño $\mathrm{M}^{1}$, Barranco $\mathrm{P}^{1,2}$, Romero $\mathrm{D}^{3}$, Domínguez-Ortega $\mathrm{J}^{1}$, Quirce $\mathrm{S}^{1,2}$

${ }^{I}$ Department of Allergy, Hospital La Paz Institute for Health Research (IdiPAZ), Madrid, Spain

${ }^{2}$ CIBER de Enfermedades Respiratorias, Ciberes, Madrid, Spain

${ }^{3}$ Department of Pneumology, Hospital La Paz, Madrid, Spain

J Investig Allergol Clin Immunol 2019; Vol. 29(1): 79-81

doi: $10.18176 /$ jiaci.0340

Key words: Severe eosinophilic asthma. Biologics. Phenotypes. Biomarkers. Anti-IL-5 antibodies.

Palabras clave: Asma grave eosinofílica. Biológicos. Fenotipos. Biomarcadores. Anticuerpos anti-IL-5.

In recent years, biological treatments have become a new therapeutic option for patients with severe asthma whose disease is not controlled with standard treatments [1]. These new therapeutic agents have been shown to be both selective and effective, as they act by blocking specific inflammatory pathways [2]. However, it is becoming increasingly difficult to select a biologic from which the patient may benefit, since there are no specific, validated biomarkers that can predict a good response. The overlap of various inflammatory pathways in asthma phenotypes could explain the lack of success of targeted therapies in certain cases [3]. Severe allergic eosinophilic asthma is an example of such a challenging scenario. In this common asthma phenotype, the underlying mechanisms responsible for asthma symptoms may be linked to heterogeneous type 2 inflammatory pathways, making patients eligible for treatment with anti-IgE, anti-IL-13, and anti-IL-5 [4]. As there are no definite recommendations to prescribe one biologic over another, treatment must be switched if asthma control is not achieved [5].

A 51-year-old man was referred to the Asthma Unit of Hospital La Paz, Madrid, Spain in 2014 with uncontrolled severe asthma. Over the previous 10 years, he had worked as a laboratory technician. His clinical history was remarkable for the following: ex-smoker for 14 years ( 7 pack-years), severe allergic asthma diagnosed in 2004, several nasal polyp surgeries, and aspirin-exacerbated respiratory disease. He had no suggestive history of occupational respiratory disease. Even though he was treated with maintenance doses of 5 to $10 \mathrm{mg}$ of prednisone, high doses of inhaled corticosteroid/ long-acting $\beta$-agonist (ICS/LABA), and leukotriene inhibitors, he had experienced 4-5 asthma exacerbations per year during the previous 4 years. Omalizumab $300 \mathrm{mg}$ monthly was initiated as add-on therapy. Despite receiving omalizumab for 1 year and prednisone $5 \mathrm{mg}$ daily, he continued to experience severe asthma attacks with frequent visits to the emergency department. Omalizumab was then stopped, and he was 
Table. Patient's Progress

\begin{tabular}{|c|c|c|c|c|c|c|}
\hline Date & Lung Function & FeNO, ppb & $\begin{array}{l}\text { Eosinophils/ } \\
\mathrm{mm}^{3}\end{array}$ & $\begin{array}{l}\text { ACT, } \\
\text { Points }\end{array}$ & Clinical Outcomes & Treatment \\
\hline March 2014 & $\begin{array}{l}\mathrm{FVC} 4.59 \mathrm{~L}(91 \%) \\
\mathrm{FEV}_{1} 2.49 \mathrm{~L}(61.4 \%) \\
\mathrm{FEV}_{1} / \mathrm{FVC} 54.38 \% \\
\text { Positive } \\
\text { bronchodilation test } \\
\left(\mathrm{FEV}_{1}+22 \% \text {, }\right. \\
\left.\mathrm{FEV}_{1} / \mathrm{FVC} 70 \%\right)\end{array}$ & 192 & 1120 & 11 & $\begin{array}{l}\text { First visit to ACD Unit } \\
\text { Inclusion in LAVOLTA } \\
\text { clinical trial }\end{array}$ & $\begin{array}{l}\text { Salmeterol/ fluticasone } \\
\text { 22/250: } 2 \text { puffs bid } \\
\text { Montelukast } 10 \mathrm{mg} / 24 \mathrm{~h} \\
\text { Tiotropium: } 18 \mu \mathrm{g} / 24 \mathrm{~h} \\
\text { Prednisone } 5 \mathrm{mg} / 24 \mathrm{~h}\end{array}$ \\
\hline March 2015 & $\begin{array}{l}\text { FVC } 5.04 \text { L }(93.3 \%) \\
\mathrm{FEV}_{1} 4.06 \mathrm{~L}(65.9 \%) \\
\mathrm{FEV}_{1} / \mathrm{FVC} 56.94 \%\end{array}$ & 98 & 1400 & 9 & $\begin{array}{l}\text { Six hospital admissions. } \\
\text { End of placebo period. } \\
\text { Initiation of } \\
\text { lebrikizumab period. }\end{array}$ & $\begin{array}{l}\text { Salmeterol/ fluticasone } \\
\text { 22/250: } 2 \text { puffs bid } \\
\text { Montelukast } 10 \mathrm{mg} / 24 \mathrm{~h} \\
\text { Tiotropium: } 18 \mu \mathrm{g} / 24 \mathrm{~h} \\
\text { Prednisone } 5-10 \mathrm{mg} / 24 \mathrm{~h}\end{array}$ \\
\hline August 2016 & $\begin{array}{l}\text { FVC } 4.71 \mathrm{~L}(95 \%) \\
\mathrm{FEV}_{1} 2.31 \mathrm{~L}(58 \%) \\
\mathrm{FEV}_{1} 7 \mathrm{FVC} 49 \%\end{array}$ & 96 & 2500 & 10 & $\begin{array}{c}\text { Five hospital admissions. } \\
\text { End of LAVOLTA } \\
\text { clinical trial. }\end{array}$ & $\begin{array}{c}\text { Prednisone } 5-30 \mathrm{mg} / 24 \mathrm{~h} \\
\text { Formoterol/fluticasone } \\
320 / 9 \mu \mathrm{g} \\
2 \text { puffs bid } \\
\text { Montelukast } 10 \mathrm{mg} / 24 \mathrm{~h} \\
\text { Tiotropium } 18 \mu \mathrm{g} \text { once daily }\end{array}$ \\
\hline $\begin{array}{l}\text { November } \\
2017\end{array}$ & $\begin{array}{l}\text { FVC } 5.16 \mathrm{~L}(104 \%) \\
\mathrm{FEV}_{1} 2.37 \mathrm{~L}(59 \%) \\
\mathrm{FEV}_{1} / \mathrm{FVC} 45 \%\end{array}$ & 95 & 1400 & 8 & $\begin{array}{l}\text { Four hospital admissions. } \\
\text { One nasal polyp surgery }\end{array}$ & $\begin{array}{c}\text { Prednisone } 10-30 \mathrm{mg} / 24 \mathrm{~h} \\
\text { Formoterol/fluticasone } \\
320 / 9 \mu \mathrm{g} \\
2 \text { puffs bid } \\
\text { Montelukast } 10 \mathrm{mg} / 24 \mathrm{~h} \\
\text { Tiotropium } 18 \mu \mathrm{g} \text { once daily }\end{array}$ \\
\hline $\begin{array}{l}\text { September } \\
2018\end{array}$ & $\begin{array}{l}\text { FVC } 4.96 \mathrm{~L}(100 \%) \\
\mathrm{FEV}_{1} 2.71 \mathrm{~L}(69 \%) \\
\mathrm{FEV}_{1} / \mathrm{FVC} \text { of } 69 \%\end{array}$ & 98 & 50 & 19 & $\begin{array}{l}\text { No more asthma attacks. } \\
\text { No further need for oral } \\
\text { corticosteroids. }\end{array}$ & $\begin{array}{l}\text { Vilanterol/ fluticasone furoate } \\
184 / 22 \text { once daily } \\
\text { Montelukast } 10 \mathrm{mg} / 24 \mathrm{~h} \\
\text { Tiotropium } 18 \mu \mathrm{g} \text { once daily } \\
\text { Mepolizumab } 100 \mathrm{mg} / 4 \mathrm{wk}\end{array}$ \\
\hline
\end{tabular}

Abbreviation: ACT, Asthma Control Test.

referred to our unit. At his first visit, a specific diagnostic protocol for uncontrolled severe asthma was applied in compliance with clinical management guidelines. Pulmonary function tests demonstrated an FVC of $4.59 \mathrm{~L}(91 \%), \mathrm{FEV}_{1}$ of $2.49 \mathrm{~L}(61.4 \%)$, and severe airflow obstruction $\left(\mathrm{FEV}_{1} / \mathrm{FVC}\right.$ $54.38 \%$ ). The bronchodilation test was positive after only $15 \mathrm{mg}$ of prednisone daily for 2 weeks (increase in $\mathrm{FEV}_{1}$ of $22 \%$ and in the $\mathrm{FEV}_{1} / \mathrm{FVC}$ ratio of $70 \%$ ). Fractional exhaled nitric oxide (FeNO) was $192 \mathrm{ppb}$. The Asthma Control Test (ACT) score was 11. The allergy work-up revealed positive skin prick test results to grass pollen, Cupressus arizonica and Lepidoglyphus destructor. Total serum IgE levels were 91.9 kU/L. Specific IgE antibodies (ImmunoCAP, Thermo Fisher) to grass pollen and $L$ destructor were negative, although they were slightly positive to $C$ arizonica pollen (1.48 $\left.\mathrm{kU}_{\mathrm{A}} / \mathrm{L}\right)$, suggesting possible concordance with asthma attacks during winter months. A complete blood count showed peripheral blood eosinophilia $\left(500 / \mathrm{mm}^{3}\right)$. During asthma attacks, blood eosinophilia increased to a maximum of $1400 / \mathrm{mm}^{3}$. An immunology work-up including IgG, IgA, IgM, antineutrophil cytoplasmic antibodies, antinuclear antibodies, and rheumatoid factor revealed no abnormalities. Microbiological and serological tests for viruses and molds were negative. A computed tomography scan of the chest and paranasal sinuses showed bronchiectasis with atelectasis in the middle lobe, and grade III nasal polyps. Other comorbidities such as gastroesophageal reflux disease or vocal cord dysfunction were ruled out. Therefore, the patient was diagnosed with severe eosinophilic allergic asthma that remained uncontrolled with standard treatments. Owing to the lack of response to this treatment and omalizumab, we proposed initiating treatment with lebrikizumab, an anti-IL-13 biologic. After giving his written informed consent, the patient was enrolled in a phase III clinical trial (LAVOLTA GB28689) [6]. He received placebo during the first year and lebrikizumab during the second. His symptoms worsened progressively throughout the 2-year clinical trial period, with 5-6 asthma exacerbations per year and 1 hospitalization. A new clinical evaluation in our unit revealed a decrease in lung function and blood eosinophilia $\left(>2500 / \mathrm{mm}^{3}\right)$. A stool test yielded a positive result for Blastocystis species. Although this infection resolved after treatment with metronidazole, blood 
eosinophilia levels remained elevated $\left(2000 / \mathrm{mm}^{3}\right)$. Finally, the clinical trial was discontinued, and the patient returned to his regular therapy with oral corticosteroids only (prednisone $5 \mathrm{mg} / 24 \mathrm{~h}$ ), high-dose ICS/LABA (320/9 $\mu \mathrm{g} 2$ puffs bid), montelukast (10 mg), and tiotropium (18 $\mu \mathrm{g}$ once daily). A year later, he underwent surgery for grade III nasal polyps and had uncontrolled asthma (FVC, 5.16 L [104\%]; FEV 1 , 2.37 L [59\%]; and $\mathrm{FEV}_{1} / \mathrm{FVC}, 45 \%$ ). We decided to shift treatment to a new biologic based on the patient's clinical history, asthma phenotype, and potential adverse effects of continuous highdose corticosteroids. The patient agreed, and anti-IL-5 therapy was administered with subcutaneous mepolizumab (100 mg every 4 weeks). After 8 months with mepolizumab, lung function improved progressively with an $\mathrm{FEV}_{1} / \mathrm{FVC}$ of $69 \%$ and an ACT score of 19 . His respiratory symptoms improved markedly, and no asthma attacks occurred despite withdrawal of oral corticosteroids. His nasal polyps remained in grade I, with no need for topical medication. He did not present any adverse reactions, despite being treated with 3 different biologic therapies. Nevertheless, a longer follow-up period would be desirable.

It is important to identify the pathway involved in specific asthma phenotypes in order to tailor treatment with biological antibodies [7]. Although these agents have helped to increase our knowledge of the pathogenesis of asthma, in many instances it remains unclear which is the best approach for patients with different clinical traits and phenotypes, some of which, such as eosinophilic and allergic asthma, can overlap [8]. In this sense, recent post hoc analyses reported that mepolizumab was safe and effective for patients of this type who had previously received omalizumab $[7,9,10]$. In the case we report, the patient was sequentially treated with 3 biological therapies that target different selective molecules; however, only mepolizumab improved his asthma symptoms. Although several biologics have been approved for uncontrolled severe asthma, no specific biomarkers have been developed to predict a good response to these therapies. This is particularly cumbersome in patients who might qualify for omalizumab and anti-IL-5 therapies [7-10]. Further studies are needed to improve our understanding of the mechanisms involved in the different features of asthma and to optimize the selection of biologics.

We report the first case of severe uncontrolled allergic eosinophilic asthma with failure of 2 biological therapies (antiIgE and anti-IL-13) and marked improvement with anti-IL-5.

\section{Funding}

The authors declare that no funding was received for the present study.

\section{Conflicts of Interest}

The authors declare that they have no conflicts of interest.
2. Kurosawa M, Sutoh E. Prospective Open-Label Study of 48-Week Subcutaneous Administration of Mepolizumab in Japanese Patients with Severe Eosinophilic Asthma. J Investig Allergol Clin Immunol. 2019. Doi: 10.18176/jiaci.0285.

3. Kim $H$, Ellis AK, Fischer $D$, Noseworthy $M$, Olivenstein $R$, Chapman KR, et al. Asthma biomarkers in the age of biologics. Allergy Asthma Clin Immunol. 2017;17:13-48

4. Menzella F, Galeone C, Lusuardi M, Simonazzi A, Castagnetti $C$, Ruggiero $P$, et al. Near-fatal asthma responsive to mepolizumab after failure of omalizumab and bronchial thermoplasty. Ther Clin Risk Manag. 2017;13:1489-93.

5. Yancey SW, Keene ON, Albers FC, Ortega H, Bates S, Bleecker ER, et al. Biomarkers for severe eosinophilic asthma. J Allergy Clin Immunol. 2017;140:1509-18.

6. Hanania NA, Korenblat P, Chapman KR, Bateman ED, Kopecky P, Paggiaro $P$, et al. Efficacy and safety of lebrikizumab in patients with uncontrolled asthma (LAVOLTA I and LAVOLTA II): replicate, phase 3, randomised, double-blind, placebocontrolled trials. Lancet Respir Med. 2016;4:781-96.

7. Magnan A, Bourdin A, Prazma CM, Albers FC, Price RG, Yancey SW, et al. Treatment response with mepolizumab in severe eosinophilic asthma patients with previous omalizumab treatment. Allergy. 2016;71:1335-44.

8. Chipps BE, Newbold P, Hirsch I, Trudo F, Goldman M. Benralizumab efficacy by atopy status and serum immunoglobulin $E$ for patients with severe, uncontrolled asthma. Ann Allergy Asthma Immunol. 2018;120:504-11.

9. Bel EH, Wenzel SE, Thompson PJ, Prazma CM, Keene ON, Yancey SW, et al. Oral Glucocorticoid-Sparing Effect of Mepolizumab in Eosinophilic Asthma. N Engl J Med. 2014;371:1189-97.

10. Ortega HG, Liu MC, Pavord ID, Brusselle GG, FitzGerald JM, Chetta A, et al. Mepolizumab Treatment in Patients with Severe Eosinophilic Asthma. N Engl J Med. 2014;371:1198207.

Manuscript received July 24, 2018; accepted for publication October 15, 2018.

Marta Sánchez-Jareño

Department of Allergy Hospital La Paz

Paseo de la Castellana 261

28046 Madrid, Spain

E-mail: martasanchezjare@gmail.com

\section{References}

1. Kim AS, Doherty TA. New and emerging therapies for asthma. Ann Allergy Asthma Immunol. 2016;116:14-7. 